the civilized world, with one-fifth of all scientists at work on defence contracts, should fill us with almost boundless pessimism. Granted, however, "the tremendous success of science, especially in the last hundred years", what is the logical connection between scientific explanation and ultimate meaning, or between scientific knowledge and ultimate belief? Or again, what is the scientific basis for the phrase "outmoded religious beliefs"? For example, is a scientific evaluation of the origin of life compatible with a theistic concept of creation? Readers may wish that Crick had here argued his case rather than merely stated his conclusion. Seen from our anthropic viewpoint, a remarkable series of "coincidences" must have taken place onwards from the initial explosion which brought the cosmos into being, so as to make possible the eventual emergence of Homo sapiens (whether or not ours is the only form of intelligent life in the Universe). These "coincidences" certainly occurred. They may be due to complex sequences of random and meaningless events. But they are also compatible with divine providence. Crick tells us that in considering the origin of life a "gut reaction" is likely to be superficial or misleading. Not all intuitions however deserve to be described in such pejorative terms. Spiritual insights are not to be despised as adequate explanations to such questions which, despite Dr Crick's almost boundless optimism, seem to transcend the fields of scientific investigation.

Hugh Montefiore is Bishop of Birmingham. quite similar new and gentler world-views, that do away with the body-mind dichotomy and the idea of the control of nature in favour of an ecological perspective in which the distinctions between subject and object, value and fact are deliberately blurred. Both authors are deeply impressed by what they see as a convergence with Eastern philosophy (YinYang, Zen Buddhism) of the ideas in quantum physics; both condemn the excesses of reductionism in favour of holism; both write for the general reader (otherwise I would not dare to review them) but in a scholarly fashion, with detailed notes and references; both regard Gregory Bateson's Mind and Nature (Dutton, 1979) as the most seminal modern work; both have the same critically respectful attitude to Freud, while preferring the development of his ideas by Carl Jung, Wilhelm Reich, Ronald Laing and Herbert Marcuse. Finally, both are centrally concerned with describing the misery of the modern world with its violence, poverty, consumerism, alienation, inflation, drug dependence, lunatic arms race and ecological destructiveness. In this last respect they are, of course, not alone. In contrast to the Meadows' Limits of Growth (Universe Books, 1972), with which they have otherwise much in common, they are cautiously optimistic because they see the new scientific world-view already emerging in North American culture.

Differences between these two books are largely matters of emphasis. Capra, a physicist, is particularly good in describing the development of physics from Newton to the present and is careful to point out which of the modern theories he adheres to are still controversial, for example, Chew's S-matrix theory. While he represents it in a language understandable to the layman and admits that he singled it out because it supports his broader views, it remains impossible for the non-physicist to understand its significance. Berman, a historian of science, writes most interestingly about Newton's psychological conflicts and complexities, and goes altogether more into psychological and political matters. While he, as much as Capra, admires Bateson whose thoughts and sources he describes in greater detail with particular emphasis on the principle of the essential incompleteness of knowledge, he also recognizes that some of Bateson's concepts are double-edged and could be exploited for totalitarian and anti-intellectual purposes; of which he strongly disapproves.

Two major common themes in these books deserve, however, critical comment. The first is the postulated link between the current malaise in the industrialized world and the mechanistic assumptions of Newtonian science; the second and related theme is the reductionism-holism issue.

A yearning to make coherent sense out of one's experience of being alive is probably universal; in Capra and Berman, 
both equally alive to the crisis-ridden state of the modern world and the state of modern science, their search for coherent meaning leads them to fuse these two realms into a world-view in which they are inextricably interdependent. Theirs is one interpretation of the past course of history and its possible future trend, but in the light of their own words they are honour-bound to admit that it is a subjective interpretation and that others are possible. One cannot take exception to their yearning for a better world nor to their description of the development of science. But there are good reasons to regard the link between them as not established. Human ingenuity in creating untold misery did not wait for the development of a mechanistic world-view. When Rome burned while Nero fiddled, when underoccupied soldiers in the fourteenth century turned brigands and plundered, raped and burned the French peasantry, devastating its agriculture, very different world-views prevailed. The holistic world-views that have for thousands of years dominated thought in the Far East have not avoided hunger, violence and overpopulation, nor the Cultural Revolution. Furthermore, the assumption that for the period with which these books deal one world-view permeated societies is questionable. People did not and do not regard themselves as machines, notwithstanding the existence of robots. In their search for meaning they have turned neither to Newton nor Niels Bohr, but increasingly in the United States to curious sects, pseudoreligions, creationism, blind imitation of Eastern practices, extrasensory perception, spiritual media and astrology - all of them dangerous in their thoughtlessness as Berman explicitly recognizes, but all of them nearer to the advocated world-view than to mechanistic conceptions.

If the argument is, however, that it is not the general population but those who hold political and economic power who exemplify the Newtonian system and thereby run us into destruction, one could equally well argue that their many misdeeds are the result of sharing essential ingredients of the new view: all too many political and economic pronouncements blur fact and value, object and subject, just

Paul and Anne Ehrlich's Extinction: The Causes and Consequences of the Disappearance of Species, reviewed in last year's Autumn Books Supplement by Kenneth Mellanby (Nature 294, 41; 1981), has just been published by the UK by Gollancz. The book was originally published by Random House in the United States. Price is $£ 9.95$, $\$ 15.95$.

- A paperback edition of Biological Energy Resources, by M. Slessor and C. Lewis (reviewed in Nature 283, 316;1980), has been published by E. \& F.N. Spon, price $£ 6.95$. as Capra and Berman advocate.

Thus one of the principal themes in these two books, the link between mechanistic science and the state of the world, stands on shaky grounds.

The other - holism versus reductionism - is treated by both authors somewhat more gingerly; both are too sophisticated to deny the enormous successes of the reductionist approach in science, but both argue that in science and the world at large holism should now replace it.

To the question of reductionism versus holism Douglas Hofstadter has surely provided the final answer in his marvellous Ant Fugue (Gödel, Escher, Bach; Harvester, 1979) with the Zen word " $m u$ " which means: unask that question. It al depends on what one wants to know. If one is after the chemical composition of cells, holism won't do; if one wants to know how people cope with the crises of life, no reduction to physiological brain-processes will provide an answer, even though brainprocesses are required in coping with life. The step from meaning to mechanism inevitably avoids the question to which an answer was originally sought. The meaningful whole is indeed different from its constituent parts and must be studied on its level, but unless the parts are properly functioning, wholes would collapse. So the parts, whether of human being, of ant colonies, of the environment or of the planetary system must be understood too.

It is true that many scientists still regard the reductionist approach as more "scientific", whatever that may mean. But the development of systems theories is already a powerful antidote to such narrow scientism; Capra and Berman furthermore quote many good minds (and some not so good) who are already grappling from a system's point of view with the central task of all scientific enterprises: to formulate significant questions and design ways to explore their implications. Whether such questions can be raised and tackled by relying on the poetic and mystical worldview of the unity of nature where everything is interdependent with everything else seems to me doubtful. The oceanic feeling of being at one with the Universe is a wonderful experience in moments of ecstasy. For the more pedestrian rational enterprise of science it must be replaced by asking questions of partial systems, small enough not to transcend the powers of the human mind.

Capra in his preface admits that with so large a scope he may have been superficial and simplistic when discussing many diverse fields of study, but he trusts that the whole of the book will be more than the sum of its parts. In contrast, this reader found many of the parts in both books informative and interesting, but the whole a bit muddled.

Marie Jahoda is Professor Emeritus of Socia Psychology and Consultant to the Science Policy Research Unit, University of Sussex.

\section{Genesis of belief}

\section{John Maddox}

Fundamentalism and American Culture: The Shaping of Twentieth Century Evangelicalism 1870-1925. By George M. Marsden. Pp. 306. ISBN 0-19-502758-2. (Oxford University Press: 1981.) £11.50, $\$ 19.95$.

LAST year's trial in Arkansas about equal time for creationism and evolution may have ended satisfactorily, but why was there in the first place a law for Judge Overton to declare unconstitutional? The wish to find out is a good reason for tackling this intricate but elegant piece of scholarship. Disappointment that there is no simple answer is overwhelmed by the richness of Dr Marsden's tale.

The book is an ecclesiastical history of the multicoloured and often warring denominations of American Protestantism in the half-century that ended in 1925 with the Scopes trial in Tennessee. Full-blown Fundamentalism was then only five years old and, Marsden says, never fully recovered from that defeat. Its end is symbolized by the death, on the Sunday after the trial ended, of William Jennings Bryan (counsel for the prosecution), once nearly President of the United States and afterwards, for a time, Woodrow Wilsor.' Secretary of State. But H. L. Mencken's savage obituary essay could not also serve as an epitaph for grass-roots Fundamentalism - there was too much of it. "Heave an egg out of a Pullman window and you will hit a Fundamentalist almost anywhere in the United States today."

By Marsden's account, Fundamentalism emerged from the reaction by Baptists and Presbyterians against the liberal theology taking hold in their denominations. But its origins lie in the "dispensational premillennialism" of the nineteenth century - the belief that the preordained history of the world specifies a final period (dispensation) of grace preceded by a second coming, itself the end-point of a period of social and moral degradation arranged by the Prince of Darkness. So the literal truth of the Bible, in particular the Revelation of St John the Divine, is the cornerstone of the faith, while saving souls against the second coming (Moody and Sankey in the United States, Spurgeon in Britain) is more important than social reform which might blunt the prophecy.

I had not known that the Fundamentalists own their name to the twelve-volume encyclopaedia of evangelical thought called The Fundamentals that was financed by the Californian oil-baron Lyman Stewart and was distributed free to more than 100,000 religious opinion-formers throughout the English-speaking world between 1910 and 1915. By then, the war between the premillennialists and the liberal theologians was well under way. There had been ructions among the Pres- 